\title{
SHORT COMMUNICATION CLUSTER OF HEPATITIS C IN A FAMILY: A TWENTY-YEAR FOLLOW-UP
}

\author{
Alberto Frosi ${ }^{1}$, Maria Franca Meloni ${ }^{2}$, Giacomo Frosi ${ }^{3}$ \\ ${ }^{1}$ IRCCS Multimedica Hospital, Sesto San Giovanni, Italy \\ 2Interventional Ultrasound, Institute of Care IGEA, Milano, Italy \\ ${ }^{3}$ Institute of Translational Medicine, University of Liverpool, Liverpool, United Kingdom
}

\section{SUMMARY}

Objective: We described an impressive cluster of hepatitis $C$ in a single family. Of nine members of the family, six - the mother and five daughters - were affected by chronic hepatitis, hepatitis $\mathrm{C}$ virus (HCV) genotype $1 \mathrm{~b}$, of which two were co-infected with hepatitis B virus (HBV). Sharing a non-disposable injection equipment for intramuscular medical care was the most likely route of contagion. Twenty years after the first observation, we performed a follow up of this family.

Methods: The clinical history was updated, and the members of the family underwent a clinical evaluation, extensive liver laboratory tests, and whole serology for hepatitis C and B. Protein chain reaction for HCV RNA was performed when indicated. The eight spouses of the offspring and their eight children underwent the same evaluation.

Results: The main findings of this study are the favourable outcome of the two members of the family mono-infected by HCV, treated with peginterferon and ribavirin (sustained response and free of liver disease), in contrast with the ominous outcome of the two members co-infected with HCV and HBV, who evolved to decompensated cirrhosis, with hepatocellular carcinoma in one case, ultimately leading to death. A further feature is the absence of transmission of HCV to the spouses and to the third generation of children of this family, consistent with the assumption that sexual and vertical transmission is unlikely.

Conclusions: A thorough epidemiological investigation of the two first generations of this family, the study of their spouses and children, and the twenty years of follow up provided a strong presumption that the infection with HCV had occurred within this family through the promiscuous use of the same inadequately sterilized glass syringe for intramuscular therapies, as was a common practice during the fifties and sixties worldwide and still is in some part of the world.

Key words: hepatitis C virus, transmission, household transmission, risk factors, iatrogenic transmission, dual infection

Address for correspondence: A. Frosi, IRCCS Multimedica Hospital, via Milanese 300, Sesto San Giovanni (MI), Italy. E-mail: a.frosi@libero.it https://doi.org/10.21101/cejph.a5027

\section{INTRODUCTION}

Hepatitis $\mathrm{C}$ virus (HCV) is a major health problem affecting more than 170 million people worldwide. The severe results of chronic HCV infection ultimately cause around 350,000 deaths per year. Aside from blood transfusion, the reuse of injection needles is considered a major route of HCV transmission (1).

Between 1994 and 1998, we followed an impressive cluster of chronic viral hepatitis in a single Italian family, mainly involving HCV but also hepatitis B virus (HBV) (2) (and additional unpublished observations). Six of nine family members had chronic HCV (genotype 1b), of whom two were co-infected with HBV. A thorough epidemiological investigation led to a suspicion that the HCV infection had spread through the promiscuous use of the same inadequately sterilized glass syringe for intramuscular therapies (2-4).

We followed up all members of this family twenty years after the first observation. We extended the study to the spouses of the offspring and the eight children of these couples.

\section{MATERIALS AND METHODS}

The patients' clinical history was updated. Informed consent was obtained. They underwent clinical evaluation and were tested for aspartate aminotransferase (AST), alanine aminotransferase (ALT), hepatitis C virus antibodies (HCVAb), hepatitis B surface antigen (HBsAg), hepatitis B surface antibody (HBsAb), and hepatitis B core antibody ( $\mathrm{HBcAb}$ ). HCV-RNA (using polymerase chain reaction method) and HCVgenotyping were performed in HCVAb-positive cases. Hepatitis $\mathrm{B}$ e antigen ( $\mathrm{HBeAg}$ ) and hepatitis $\mathrm{B}$ e antibody ( $\mathrm{HBeAb}$ ) were analysed in HBsAg-positive cases. Liver biopsy was performed in part of the subjects when indicated in different periods of their observation. The eight spouses of the offspring and the eight children of these couples underwent a clinical interview and had the same tests performed. Neither of them required invasive procedures.

The work has been conducted in accordance with local ethical principles and recommendations, and can be regarded as an exten- 
sion of our common good clinical practice of care and prevention of viral hepatitis.

\section{RESULTS}

The mother, who had HCV-compensated cirrhosis, had died of end-stage heart failure at 76 years of age. Before marriage, she had been in sanatoria and had undergone artificial pneumothorax, suggesting an iatrogenic origin of her HCV infection. The father had died of cardiovascular disease three years before our first observation, and his $\mathrm{HCV} / \mathrm{HBV}$ status is unknown. Two daughters with chronic HCV hepatitis had had a sustained response to 48 weeks of treatment with peginterferon and ribavirin; they were free from liver disease at the followup. Two daughters with HCV-HBV co-infection had developed progressive decompensated liver cirrhosis; one also developed hepatocellular carcinoma (HCC). Both of them had undergone orthotopic liver transplantation but died soon after the procedure. Another daughter had been diagnosed with chronic hepatitis $\mathrm{C}$ with normal transaminases, and was in relatively good health at the follow-up (Table 1).

There was no evidence of $\mathrm{HCV} / \mathrm{HBV}$ infection in the eight spouses and eight children of the third generation (the small number of the latter reflects the dramatic decline in the natality in our country during only one generation). Notably, our survey evidenced the cessation of unnecessary and unsafe injections to the children of the third generation of this family.

\section{DISCUSSION}

Overall, the present study included 25 individuals belonging to three generations. To the best of our knowledge, this is the first long-term follow-up of a single family with a very high prevalence of hepatitis $\mathrm{C}$.

The disappearance of $\mathrm{HCV}$ in the third generation of this family reinforces the assumption that the most likely route of infection in the second generation was not vertical, but horizontal (and iatrogenic) $(4,5)$. The introduction of disposable syringes has contributed to a dramatic reduction in the global spread of $\mathrm{HCV}$ (4). The results from the spouses of the HCV-infected family members are in agreement with data from large studies indicating that sexual transmission of $\mathrm{HCV}$ within heterosexual monogamous couples is unlikely (6). Of the original family members with the worst prognosis, one developed decompensated cirrhosis and the other HCC, ultimately resulting in death; both of them had HCV/ HBV co-infection, a notable feature (7).

Table 1. Early data (1994-1998) of the family cluster of HCV (and HBV), mother and eight children, and results of the followup after twenty years

\begin{tabular}{|c|c|c|c|c|c|}
\hline $\begin{array}{l}\text { Family members } \\
\text { age (years) } \\
\text { in 1994, sex }\end{array}$ & Anti-HCV & $\begin{array}{c}\text { HCV-RNA } \\
\text { and genotype }\end{array}$ & $\begin{array}{l}\text { Positive HBV serum } \\
\text { markers }\end{array}$ & Diagnosis & $\begin{array}{l}\text { 20-year follow-up } \\
\text { (year of the event) }\end{array}$ \\
\hline \multicolumn{6}{|l|}{ Mother } \\
\hline $1(65$, female $)$ & + & $+1 b$ & None & $\begin{array}{l}\text { Chronic hepatitis C } \\
\text { (biopsy) }\end{array}$ & $\begin{array}{c}\text { Died of a cause unrelated } \\
\text { to liver disease (2005) }\end{array}$ \\
\hline \multicolumn{6}{|l|}{ Children } \\
\hline \multirow{3}{*}{2 (48, female) } & \multirow{3}{*}{+} & \multirow{3}{*}{$+1 b$} & $\mathrm{HBsAg}$ & \multirow{3}{*}{$\begin{array}{l}\text { Hepatic cirrhosis } \\
\text { (biopsy) }\end{array}$} & HCC (2004) \\
\hline & & & $\mathrm{HBcAb}$ & & OLT (2005) \\
\hline & & & $\mathrm{HBeAg}$ & & Death (2005) \\
\hline \multirow{3}{*}{$3(45$, female $)$} & \multirow{3}{*}{+} & \multirow{3}{*}{$+1 b$} & $\mathrm{HBsAg}$ & \multirow{3}{*}{$\begin{array}{l}\text { Hepatic cirrhosis } \\
\text { (biopsy) }\end{array}$} & $\begin{array}{c}\text { Decompensated cirrhosis } \\
(2008)\end{array}$ \\
\hline & & & $\mathrm{HBcAb}$ & & OLT (2009) \\
\hline & & & $\mathrm{HBeAb}$ & & Death (2009) \\
\hline \multirow{2}{*}{$4(39$, male $)$} & \multirow{2}{*}{-} & \multirow{2}{*}{-} & HBsAb & \multirow{2}{*}{ Healthy } & \multirow{2}{*}{ Healthy } \\
\hline & & & $\mathrm{HBcAb}$ & & \\
\hline $5(35$, male $)$ & - & - & None & Healthy & Healthy \\
\hline $6(32$, female $)$ & + & $+1 b$ & $\mathrm{HBsAb}$ & $\begin{array}{l}\text { Chronic hepatitis C } \\
\text { (biopsy) }\end{array}$ & $\begin{array}{l}\text { Treatment with peginter- } \\
\text { feron and ribavirin (2004): } \\
\text { sustained response }\end{array}$ \\
\hline $7(29$, female $)$ & + & $+1 b$ & None & $\begin{array}{l}\text { Chronic hepatitis C } \\
\text { (biopsy) }\end{array}$ & $\begin{array}{l}\text { Treatment with peginter- } \\
\text { feron and ribavirin (2001): } \\
\text { sustained response }\end{array}$ \\
\hline $8(28$, female $)$ & - & - & HBsAb (vaccine) & Healthy & Healthy \\
\hline $9(26$, female $)$ & + & $+1 b$ & None & $\begin{array}{l}\text { Mild chronic hepatitis C } \\
\text { (biopsy) }\end{array}$ & $\begin{array}{l}\text { Treatment with peginter- } \\
\text { feron and ribavirin not } \\
\text { tolerated. In relatively } \\
\text { good health }\end{array}$ \\
\hline
\end{tabular}

HCV - hepatitis C virus; RNA - ribonucleic acid; HBV - hepatitis B virus; + positive; - negative; HCC - hepatocellular carcinoma; OLT - orthotopic liver transplantation 


\section{CONCLUSION}

Poor injection practices have been reported worldwide and are still common in developing and transitional countries, but also in some western countries and in Japan during the 1950s and 60s.

The combination of injection overuse and unsafe practices (not only among injecting drug users but also for minor medical care) results in a major route of transmission for $\mathrm{HBV}$ and $\mathrm{HCV}$ (8). Even in the present era of revolutionary but expensive new treatments for HCV hepatitis, in absence of a vaccine for this communicable disease, primary prevention must still be regarded as the cornerstone to disease control.

\section{Conflicts of Interests}

None declared

\section{Authors' Contribution}

All authors contributed equally to the manuscript.

\section{Adherence to Ethical Standards}

The work has been performed in accordance with local ethical principles and recommendations.

\section{REFERENCES}

1. Webster DP, Klenerman P, Dusheiko GM. Hepatis C. Lancet. 2015;385(9973):1124-35.

2. Frosi A, Ragni MC, Salvaggio L, Vezzoli S, Vezzoli F. Hepatitis C virus. Lancet. 1995;345(8943):189-91.

3. de Waure C, Cefalo C, Chiaradia G, Sferrazza A, Miele L, Gasbarrini G, et al. Intrafamilial transmission of hepatitis $\mathrm{C}$ virus in Italy: a systematic review. J Epidemiol Community Health. 2010;64(10):843-8.

4. Chiaramonte M, Stroffolini T, Lorenzoni U, Minniti F, Conti S, Floreani $\mathrm{A}$, et al. Risk factors in community-acquired chronic hepatitis $\mathrm{C}$ virus infection: a case-control study in Italy. J Hepatol. 1996 Feb;24(2):129-34.

5. Yeung LT, King SM, Roberts EA. Mother-to-infant transmission of hepatitis C virus. Hepatology. 2001;34(2):223-9.

6. Vandelli C, Renzo F, Romanò L, Tisminetzky S, De Palma M, Stroffolini $\mathrm{T}$, et al. Lack of evidence of sexual transmission of hepatitis $\mathrm{C}$ among monogamous couples: results of a 10-year prospective follow-up study. Am J Gastroenterol. 2004 May;99(5):855-9.

7. Liu CJ, Chen PJ. Updates on the treatment and outcomes of dual chronic hepatitis $\mathrm{C}$ and B virus infection. World $\mathrm{J}$ Gastroenterol. 2014;20(11):2955-61.

8. Hutin YJ, Heuri AM, Armstrong GL. Use of injection in healthcare setting worldwide, 2000: literature review and regional estimates. BMJ. 2003;327(7423):1075. doi: 10.1136/bmj.327.7423.1075.

Received December 31, 2016 Accepted in revised form March 8, 2019 